\title{
KOMUNIKASI PARTISIPATIF BERBASIS GENDER PADA RELAWAN PEREMPUAN JURU PEMANTAU JENTIK
}

\author{
Sofia Aunul ${ }^{1}$ Riswandi $^{2}$ Fitrie Handayani ${ }^{3}$ \\ ${ }^{1,2}$ Universitas Mercu Buana \\ ${ }^{3}$ Universitas Bina Nusantara \\ Email: sofia_aunul@mercubuana.ac.id
}

Diterima : 27 Oktober 2020

Disetujui : 19 Januari 2021

Diterbitkan : 26 Februari 2021

\begin{abstract}
Abstrak
Perempuan sebagai bagian dari masyarakat mempunyai partisipatif aktif dalam pembangunan seperti penentuan perencanaan pembangunan sampai pada proses evaluasi hasil dari partisipatif mereka dalam pembangunan yang sesuai dengan kebutuhan yang dirasakan. Salah satu wujud implementasi tersebut adalah dengan menjadi Juru Pemantau Jentik (Jumantik). Penelitian ini bertujuan mengetahui komunikasi partisipatif berbasis gender relawan Jumantik dalam kaitannya menjaga dan memberantas jentik nyamuk di lingkungan RW 09 Kelurahan Petukangan Utara Jakarta Selatan. Penelitian ini menggunakan pendekatan kualitatif deskriptif dengan menggunakan wawancara dan observasi untuk mendapatkan data. Hasil penelitian didapatkan bahwa partisipatif perempuan dalam komunikasi partisipatif sebagai sukarelawan Jumantik merupakan kesadaran untuk dapat menjaga lingkungan mereka. Bentuk komunikasi partisipatif yang digunakan berdasarkan model multi-track-monologis, dialogis dan kombinasi. Partisipasi perempuan dalam pengawasan lingkungan program Pemberatasan Sarang Nyamuk (PSN) juga turut meningkatkan pengetahuan dan keterampilan mereka yang pada akhirnya pengetahuan dan keterampilan tersebut tidak hanya mereka sendiri rasakan namun juga lingkungan masyarakat di mana mereka tinggal.
\end{abstract}

Kata Kunci: komunikasi partisipatif, perempuan, jumantik

\begin{abstract}
Women as part of society have an active participation in development, from determining development planning to the process of evaluating the results of their participation in development according to their perceived needs. One form of implementation is by becoming a larva observer (jumantik). This study aims to determine how gender-based participation communication of jumantik volunteers in relation to maintaining and eradicating mosquito larvae in $R W 09$, Petukangan Utara, South Jakarta. This study used a descriptive qualitative approach using interviews and observation to obtain data. The results showed that women's participation in participatory communication as jumantik volunteers was an awareness to be able to protect their environment. The form of participatory communication used is based on a multi-track model - monological, dialogical and combination. The participation of women in the environmental monitoring of the PSN program also increases their knowledge and skills, so that in the end these knowledge and skills are not only felt by them but also the community environment in which they live.
\end{abstract}

Keywords: participatory communication, women, jumantik 


\section{PENDAHULUAN}

Perempuan sebagai bagian dari masyarakat mempunyai partisipatif aktif dalam pembangunan seperti penentuan perencanaan pembangunan sampai pada proses evaluasi hasil dari partisipatif mereka dalam pembangunan yang sesuai dengan kebutuhan yang dirasakan (Rinawati, 2004). Lebih lanjut, Ainul Mardiyah (Saleh, 2014) menyatakan perempuan dapat ikut serta dalam pengelolaan lingkungan yang mana mereka akan terlibat dalam suatu perkumpulan/organisasi lingkungan dan melakukan sosialisasi. Dengan demikian perempuan lainnya pun dapat mudah memahami dan menerima keikutsertaan mereka dalam pembangunan.

Perempuan dalam komunikasi lingkungan merupakan implementasi sikap peduli lingkungan yang pada akhirnya juga akan memberikan dampak baik bagi dirinya dan masyarakat sekitarnya. Salah satu wujud implementasi tersebut adalah dengan menjadi Juru Pemantau Jentik (Jumantik). Jentik nyamuk merupakan salah satu tahap dalam siklus hidup nyamuk. Keberadaan jentik nyamuk erat kaitannya dengan angka kejadian deman berdarah dengue (DBD) seperti yang dilansir pada situs berita online suara.com menyatakan bahwa DKI Jakarta merupakan salah satu Provinsi terbesar yang penderitanya sampai Maret 2019 tercatat 2.883 (Febrinastri, 2019).

Pemerintah Provinsi DKI Jakarta dalam hal ini dinas kesehatan berupaya meningkatkan Pemberantasan Sarang Nyamuk (PSN). Salah satu upaya yang dilakukan untuk pemberantasan sarang nyamuk adalah pembentukan kader Jumantik yang bertujuan melibatkan mereka di tiap wilayah Rukun Tetangga (RT) sehingga mereka dapat membina warga lainnya untuk sama-sama membasmi jentik.

Sebuah kajian riset menyatakan bahwa dalam sistem kewaspadaan dini DBD, JUMANTIK mempunyai peran yang sangat penting karena pemantauan keberadaaan jentik dapat menghambat pertumbuhan vektor penular DBD. Keaktifan kader Jumantik dalam memantau lingkungannya merupakan langkah penting untuk mencegah meningkatnya angka kasus DBD (Pratamawati, 2012). Sementara itu, (Yuliani, 2019) pada pemberitaan dalam Media Indonesia melaporkan Kadinkes DKI Jakarta Widyastuti berpendapat setiap warga harus bisa berperan sebagai jumantik bagi keluarganya dan juga mereka diharapkan untuk dapat memberikan motivasi dan edukasi masyarakat pada wilayah binaannya. Lebih lanjut, setiap satu rumah diharapkan mempunyai kader Jumantik bagi rumahnya sendiri agar dapat melakukan kegiatan PSN secara mandiri selain pemantauan dari kader Jumantik lainnya.

Pemerintah melalui Kementerian Kesehatan berupaya untuk mengatur program PSN pada Surat Nomor PM.01.11/MENKES/591/2016 tanggal 8 November 2016 mengatur pelaksanaan Pemberantasan Sarang Nyamuk (PSN) 3M Plus dengan Gerakan satu rumah satu Jumantik (Juru Pemantau Jentik). Hal ini merupakan suatu strategi yang ditujukan untuk melakukan penguatan terhadap pelayanan kesehatan dengan tujuan kegiatan promotif dan pencegahan yang dalam hal ini adalah penyakit Arbovirus khususnya DBD. Pemerintah berupaya untuk menggerakkan lapisan masyarakat karena Arbovirus berkembangbiak di dalam ataupun di luar lingkungan rumah yang menjadi tempat penularan DBD.

Pada tahun 1992 terdapat petunjuk teknis penggerakan pemberantasan sarang nyamuk (PSN) demam berdarah dengue dimana kader Jumantik dibentuk sebagai kelompok 
kerja dalam melakukan pemberantasan pada wilayah setingkat desa yang merupakan bagian dari Lembaga Ketahanan Masyarakat Desa (LKMD). Jumantik merupakan petugas sukarela berasal dari bagian masyarakat yang ikut serta bertanggung jawab dalam melakukan kegiatan PSN seperti pemantauan dan pelaporan hasil pemantauan kepada kelurahan secara rutinn dan berkesinambungan (Pratamawati, 2012).

Kader Jumantik mempunyai peran dalam melakukan pemantauan dan oencegahan DBD sebagai berikut: (1) menjadi bagian dari Pemantauan Jentik Berkala (PJB) di lingkungan rumah mereka, (2) memberikan informasi dan edukasi berupa penyuluhan kepada anggota keluarga dan masyarakat di lingkungan mereka, (3) melakukan pencatatan dan pelaporan hasil kegiatan PSN yang dilakukan secara berkala (mingguan dan bulanan) kepada Rukun Warga (RW), kepala desa maupun puskesmas setempat, (4) melakukan kegiatan PSN dan pemberantasan DBD dengan memberikan bubuk abate dan ikan pemakan jentik.

Susunan organisasi program PSN terdiri dari kepala desa/ lurah selaku ketua umum dan kader Jumantik sebagai anggotanya. Susunan ini disesuaikan dengan kebutuhan dan kondisi masyarakat setempat dimana hal ini berdasarkan ketentuan bahwa Kelompok Kerja (Pokja) merupakan bagian dari LKMD yang mana Pokja dibentuk untuk pelaksanaan jenis kegiatan sesuai dengan bidang, tugas dan fungsinya.

Selain peran yang dijalankan, kader Jumantik juga memiliki tugas dan fungsi sebagai berikut: (1) melakukan kordinasi kegiatan Jumantik, (2) membuat dan menetapkan waktu pertemuan secara berkala, (3) membuatkan laporan secara berkala, (4) menetapkan langkahlangkah pemecahan masalah, (5) menyiapkan undangan dan tempat pertemuan (6) melakukan pelaporan secara berkala kepada ketua LKMD tentang kegiatan Pokja, (7) menyiapkan bahan pertemuan seperti data yang didapatkan dari hasil PJB, (8) memberikan bimbingan pelaksanaan pemeriksaan jentik, (9) memberikan penyuluhan dan bimbingan teknis penyuluhan kepada kader Jumantik, (10) melakukan pencatatan kegiatan penyuluhan, (11) melaksanakan pemeriksaan jentik di 30 rumah secara acak di tiap RW dan menyampaikan hasil pemeriksaan tersebut secara berkala sekurang-kurangnya tiap 3 bulan kepada ketua LKMD, (11) memberikan pelatihan kader jumantik, (12) melakukan perencanaan kegiatan masyarakat untuk melaksanakan PSN, (13) menyiapkan masyarakat untuk dapat ikut serta dalam pelaksanaaan penanggulangan penyakit DBD.

Sebelum kader Jumantik melaksanakan PSN, mereka terlebih dahulu diberikan pelatihan khusus dan gambaran mengenai wilayah PSN mereka. Pada saat pelaksanaan, mereka melakukan pemantauan seminggu sekali dan jika pada saat pemantauan ditemukan jentik nyamuk, maka Jumantik memberikan imbauan kepada penghuni/pemilik rumah untuk membersihkan tempat dimana ditemukan jentik tersebut. Kemudian Jumantik akan mencatat dan melaporkan kegiatan PSN.

Pada dasarnya komunikasi mempunyai peranan yang sangat penting dalam mengimplementasikan sebuah program pemerintahan/ pembangunan (Rinawati, 2006) yang selanjutnya konsep komunikasi dan pembangunan ini disebut dengan komunikasi partisipatif. Komunikasi partisipatif (Hadiyanto, 2008) merupakan sebuah kegiatan terencana sebagai strategi dan pendekatan komunikasi dalam proses pembanguinan. Komuniakasi 
partisipatif dipandang sebagai sarana ampuh yang dapat menfasilitasi proses partisipatif apabila proses tersebut sesuai dengan dinamika pembangunan di tingkat lokal.

Proses yang dimaksud tersebut adalah keikutsertaan (parsitipasi) komunitas yang merupakan aktivitas keterlibatan kelompok komunitas yang berbeda yang bersama-sama dengan pemangku kepentingan lainnya (stakeholder) seperti agen pembangunan, para peneliti dan para pembuat keputusan. Secara umum pemangku kepentingan (stakeholder) merupakan anggota masyarakat, komunitas, aktivis, aparat pemerintah, Lembaga Swadaya Mayarakt (LSM) dan para pembuat kebijakan yang terlibat pada pembangunan yang sedanng berlangsung.

Servaes, J. \& Malikhao, P. (2015) menyatakan bahwa komunikasi partisipatif untuk perubahan sosial melihat orang sebagai inti dari pembangunan. Pembangunan berarti mengangkat semangat komunitas lokal untuk bangga dengan budaya, kecerdasan, dan lingkungannya sendiri. Pembangunan bertujuan untuk mendidik dan merangsang orang agar aktif dalam perbaikan diri dan bersama sambil mempertahankan ekologi yang seimbang. Partisipatif otentik, meskipun banyak didukung dalam literatur, tidak menjadi perhatian semua orang. Karena konsentrasi lokal mereka, program partisipatif, pada kenyataannya, tidak mudah diimplementasikan, juga tidak dapat diprediksi atau dikendalikan.

Komunikasi partisipatif diartikan sebagai suatu proses komunikasi dialogis atau dua arah yang akan menghasilkan pemahaman yang sama pada pesan yang disampaikan. Seperti yang dikutip oleh I. Satriani, P. Muljono, R.W.E. Lumintang. 2011; Syarah, 2016; Dewi, M \& Nulul, N.A, 2018 dalam Rahim (2004) menyampaikan konsep yang akan mendukung konsep komunikasi partisipatif sehingga terciptanya pemberdayaan. Komunikasi partisipatif menurut Hadiyanto (2008) merupakan sebuah kegiatan terencana sebagai strategi dan pendekatan komunikasi dalam proses pembangunan. Komunikasi partisipatif dipandang sebagai sarana ampuh yang dapat menfasilitasi proses partisipatif apabila proses tersebut sesuai dengan dinamika pembangunan di tingkat lokal. Proses-proses partisipatif yang dimaksud adalah adanya partisipatif komunitas, yakni adanya keterlibatan aktif kelompok komunitas yang berbeda, bersama-sama pemangku kepentingan lainnya dan beberapa agen pembangunan serta peneliti yang bekerja dengan komunitas serta para pengambil keputusan.

Servaes, J. \& Malikhao, P. (2015) menyatakan bahwa komunikasi partisipatif untuk perubahan sosial melihat orang sebagai inti dari pembangunan. Komunikasi partisipatif adalah pertukarannya informasi antara pihak-pihak yang terlibat dalam proses pembangunan melalui dialog untuk mencapai saling pengertian (pengertian bersama) dan konsensus untuk proses pengambilan keputusan. Inti dari dialog adalah pengakuan dan menghormati dan mempertimbangkan peserta komunikasi sebagai subjek bukan objek dan hal ini menegaskan bahwa setiap orang memiliki kesamaan hak untuk berbicara dan mendengarkan. Dialog sebagai dasar komunikasi pada program pembangunan merupakan suatu bentuk partisipatif yang ditandai dengan adanya pertukaran informasi dan bekerja sama dengan pihak luar (aparat penyelenggara program, fasilitator dan elit lokal) dalam proses pengambilan keputusan (Aminah, 2016).

Model multi-track yang lahir karena adanya kompleksitas dari pendekatan operasional dan tantangan pembangunan yang menjadi kerangka komunikasi metodologis yang bertujuan untuk memberikan gambaran mengenai fleksibilitas dan kemampuan 
beradaptasi untuk berbagai situasi, model mempunyai pendekatan komunikasi yang dibagi menjadi dua kategori dasar: komunikasi monologis dan dialogis (Tufte \& Mefalopulos, 2009). Komunikasi monologis mengadopsi komunikasi satu arah yang dalam konteks ini seperti penyebaran informasi, kampanye media, dan pendekatan difusi lainnya. Pendekatan yang kedua adalah komunikasi dialogis atau komunikasi dua arah, dimana proses dan keluarannya terbuka dan ruang lingkupnya ditujukan untuk mengeksplorasi masalah dan menghasilkan pengetahuan baru serta solusi yang dapat ditawarkan, bukan hanya sekedar penyampaian informasi.

Tabel 1 Model Multi-Track

\begin{tabular}{l|l|l|l|l}
\hline \multirow{2}{*}{} & \multicolumn{2}{|c|}{ Konologis } & \multicolumn{2}{c}{$\begin{array}{c}\text { Dialogis } \\
\text { Komunikikasi dua arah }\end{array}$} \\
\hline & Informasi & Persuasi & Eksplorasi & Pemberdayaan \\
\hline Tujuan Utama & $\begin{array}{l}\text { Meningkatkan } \\
\text { awareness dan } \\
\text { pengetahuan }\end{array}$ & $\begin{array}{l}\text { Mendukung } \\
\text { perubahan } \\
\text { sikap dan } \\
\text { perilaku }\end{array}$ & $\begin{array}{l}\text { Menilai, } \\
\text { menyelidiki } \\
\text { dan } \\
\text { menganalisa } \\
\text { isu dan } \\
\text { mencegah } \\
\text { konflik }\end{array}$ & $\begin{array}{l}\text { Membangun } \\
\text { keikutsertaan } \\
\text { stakeholder }\end{array}$ \\
\hline $\begin{array}{l}\text { Referensi } \\
\text { Model }\end{array}$ & $\begin{array}{l}\text { Monologis } \\
\text { Komunikasi } \\
\text { satu arah }\end{array}$ & $\begin{array}{l}\text { Monologis } \\
\text { Komunikasi } \\
\text { satu arah }\end{array}$ & $\begin{array}{l}\text { Dialogis } \\
\text { Komunikasi } \\
\text { dua arah }\end{array}$ & $\begin{array}{l}\text { Komunikasi } \\
\text { dua arah }\end{array}$ \\
\hline Media & $\begin{array}{l}\text { Penggunaan } \\
\text { media massa }\end{array}$ & $\begin{array}{l}\text { Penggunaan } \\
\text { media massa }\end{array}$ & $\begin{array}{l}\text { Penggunaan } \\
\text { pendekatan } \\
\text { interpersonal }\end{array}$ & $\begin{array}{l}\text { Menggunaan } \\
\text { dialog untuk } \\
\text { mengajak } \\
\text { parsipasi }\end{array}$ \\
\hline
\end{tabular}

Sumber : Tufte \& Mefalopulos (2009)

Kategorisasi ini seperti pada tabel 1 menunjukkan dengan jelas bahwa metode dan alat komunikasi apa yang seharusnya digunakan dalam inisiatif khusus. Tidak ada pendekatan yang cocok secara universal, tetapi masing-masing harus diterapkan secara tepat sesuai dengan keadaan dan tujuan yang diinginkan. Selain komunikasi monologis dan dialogis, komunikasi gabungan keduanya sangat mungkin terjadi. Dari penjelasan di atas, penelitian ini bertujuan untuk mengetahui bagaimana komunikasi partisipatif berbasis gender relawan jumantik dalam kaitannya menjaga dan memberantas jentik nyamuk di lingkungan RW 09 Kelurahan Petukangan Utara Jakarta Selatan DKI Jakarta.

\section{METODOLOGI PENELITIAN}

Penelitian ini merupakan penelitian kualitatif yang bertujuan untuk menganalisis dan mendeskripsikan fenomena atau obyek penelitian melalui aktivitas sosial, sikap dan persepsi orang secara individu atau kelompok (Sugiyono, 2019). Penelitian ini menggunakan pendekatan kualitatif deskriptif dengan menggunakan teknik wawancara, observasi dan 
dokumentasi untuk mendapatkan data penelitian. Objek penelitian ini adalah kegiatan komunikasi partisipatif dan yang menjadi subyek pebelitian ini adalah relawan perempuan Jumantik di RW 09 Kelurahan Petukangan Utara Jakarta Selatan DKI Jakarta serta penelitian ini dilakukan pada bulan Januari sampai Februari 2020 sebelum pemerintah mengeluarkan keputusan Pembatasan Sosial Berskala Besar (PSBB) pandemi covid-19.

Wawancara yang percakapan antara periset seseorang yang berharap mendapatkan informasi dan informan seseorang yang diasumsikan mempunyai informasi penting tentang suatu objek (Kriyantono, 2014). Wawancara dilakukan kepada delapan informanlima orang petugas Jumantik, dua orang warga dan satu kepala rukun warga. Pemilihan informan dilakukan melalui teknik sampel secara purposif yang mana informan memiliki pengetahuan mengenai elemen- elemen yang terdapat pada individu dan tujuan penelitian yang hendak dilakukan (Morissan, Wardhani, \& Umarella, 2012). Observasi merupakan kegiatan untuk memperoleh gambaran riil suatu peristiwa atau kejadian untuk menjawab pertanyaan penelitian dan observasi dilakukan peneliti untuk mengetahui bagaimana kegiatan PSN dilakukan. Sedangkan dokumentasi dilakukan untuk melengkapi teknik wawancara dan observasi berupa foto. Penelitian ini menggunakan teknik analisa data Huberman dan Miles yang mana kegiatan analisis terdiri dari tiga jenis kegiatan yang terjadi secara stimultan (tidak hanya berurutan) yaitu melakukan reduksi data, melakukan penyajian data, dan melakukan penarikan kesimpulan/verifikasi. Teknik triangulasi sumber digunakan untuk mendapatkan validitas data secara kualitatif dan penelitian ini menggunakan informan warga dan kepala rukun warga sebagai implementasi dari triangulasi sumber.

\section{HASIL DAN PEMBAHASAN}

Pemerintah mencanangkan Program Indonesia Sehat melalui Surat Nomor PM.01.11/MENKES/591/2016 tanggal 8 November 2016 yang mengatur pelaksanaan Pemberantasan Sarang Nyamuk (PSN) sebagai upaya penyusunan strategi penguatan pelayana kepada masyarakat. Program ini dilaksanakan melalui pendekatan komunikasi partisipatif yang mana pemerintah memberikan ruang gerak bagi masyarakat untuk ikut serta (partisipasi) dalam pelaksanaan program ini.

\section{Keikutsertaan (Partisipasi) Perempuan sebagai Juru Pantau Jentik}

Juru Pemantau Jentik (Jumantik) merupakan petugas kesehatan atau anggota masyarakat yang secara sukarela memantau keberadaan jentik nyamuk Aedes Aegypti di lingkungannya. Mereka memiliki tanggung jawab mendorong masyarakat melakukan Pemberantasan Sarang Nyamuk (PSN) secara rutin.

Sukrarelawan yang menjadi obyek penelitian ini adalah perempuan yang berpartisipatif untuk menjaga lingkungan agar terbebas dari vector Aedes Aegepti. Berdasarkan hasil wawancara didapatkan informasi bahwa motivasi dari partisipatif mereka adalah bentuk kepekaan mereka sebagai respon tingginya angka DBD. 
Tabel 2 Motivasi Sukarelawan

\begin{tabular}{|c|c|c|c|c|}
\hline Informan & Usia & Pekerjaan & $\begin{array}{c}\text { Lama Menjadi } \\
\text { Sukarelawan } \\
\text { Jumantik }\end{array}$ & $\begin{array}{c}\text { Motivasi Menjadi } \\
\text { Sukarelawan } \\
\text { Jamantik }\end{array}$ \\
\hline 1 & 46 & $\begin{array}{l}\text { Ibu Rumah } \\
\text { Tangga }\end{array}$ & $\begin{array}{l}2014 \text { (sebelum ada } \\
\text { program Indonesia } \\
\text { Sehat tahun 2016) }\end{array}$ & $\begin{array}{l}\text { Panggilan hati dan } \\
\text { ikhlas }\end{array}$ \\
\hline 2 & 67 & $\begin{array}{l}\text { Ibu Rumah } \\
\text { Tangga }\end{array}$ & $\begin{array}{l}2012 \text { (sebelum ada } \\
\text { program Indonesia } \\
\text { Sehat tahun 2016) }\end{array}$ & Senang dan ikhlas \\
\hline 3 & 43 & $\begin{array}{l}\text { Ibu Rumah } \\
\text { Tangga }\end{array}$ & 2017 & $\begin{array}{lr}\text { Adanya } & \text { kesadaran } \\
\text { pribadi } & \text { untuk } \\
\text { memberikan } & \\
\text { pemahaman } & \text { kepada } \\
\text { warga } & \end{array}$ \\
\hline 4 & 38 & $\begin{array}{l}\text { Ibu Rumah } \\
\text { Tangga }\end{array}$ & 2016 & $\begin{array}{l}\text { Sosialisasi dengan } \\
\text { warga }\end{array}$ \\
\hline 5 & 56 & $\begin{array}{l}\text { Ibu Rumah } \\
\text { Tangga }\end{array}$ & 2016 & Agar warga sehat \\
\hline
\end{tabular}

Sumber: Data Olahan Peneliti

Semua informan adalah ibu rumah tangga murni dalam artian mereka tidak mempunyai aktivitas ekonomi lainnya sehingga aktivitas ini mereka jalankan dengan komitmen tinggi tanpa mengharapkan nilai ekonomi yang mereka akan dapatkan dari aktivitas pemantauan jentik ini. Hal ini seperti yang diungkapkan oleh informan 1 sebagai kordinator

“ kalau ibu rumah tangga yang punya usaha, mereka akan mengharapkan imbalan ekonomi ..sedangkan jumantik ini tidak ada penghasilannya...ibu rumah tangga biasa lebih berkomitmen.."

Untuk itu pemilihan sukarelawan pun Rukun Warga dan Rukun Tetangga memilih perempuan yang berstatus ibu rumah tangga dikarenakan mereka diharapkan mempunyai komitmen tinggi baik secara fisik dan waktu karena aktivitas pemantauan jentik dilakukan secara berkala pada hari Selasa dan Jumat yang masing-masing kelompok jumantik akan mengunjungi 50 rumah setiap minggunya. Berikut wawancara dengan informan 3 terkait hal di atas,

“..capek sih, setiap kunjungan itu 50 rumah..mulai habis asar sekitar jam 1530 sampai 1730..tapi senang karena bisa bantu warga"

Hal senada disampaikan oleh informan 2,

"Kita ada tim. 1 RT 3 orang. Jadi untuk bagi tugasnya setiap orang cari 50 rumah, 50 rumah, 50 rumah. Kalau aku dobel, kadang jadi totalnya 200” 
Tabel 3 Sumber Informasi Jumantik dan Rekrutmen

\begin{tabular}{|c|l|l|}
\hline Informan & $\begin{array}{l}\text { Sumber Info tentang } \\
\text { Jumantik }\end{array}$ & \multicolumn{1}{|c|}{$\begin{array}{c}\text { Sumber Info } \\
\text { Rekrutmen }\end{array}$} \\
\hline 1 & $\begin{array}{l}\text { Kelurahan yang } \\
\text { diinisiasi oleh PKK }\end{array}$ & PKK \\
\hline 2 & $\begin{array}{l}\text { Kelurahan melalui } \\
\text { Puskesmas }\end{array}$ & Kordinator kelurahan \\
\hline 3 & RT & RT \\
\hline 4 & Senior Jumantik & Senior Jumantik \\
\hline 5 & RW & RT \\
\hline
\end{tabular}

Sumber: Data Olahan Peneliti

Sebagai salah satu program pemerintah, aktivitas PSN yang dilakukan oleh sukarelawan jumantik melalui kordinasi mulai struktur Kelurahan sampai akhir nya Rukun Tetangga. Selain struktur tersebut, struktur penunjang juga berperan dalam penyebaran informasi mengenai Jumantik dan perekrutannya seperti PKK dan Puskesmas.

\section{Komunikasi Partisipatif Sukarelawan Jumantik}

Komunikasi secara umum diartikan sebagai suatu kegiatan penyampaian informasi (pesan, ide, atau gagasan) dari komunikator kepada komunikan yang dilakukan baik secara verbal maupun nonverbal. Aktivitas komunikasi sukarelawan jumantik terjalin dalam komunikasi interpersonal yang intens dan hal ini akan memudahkan kordinasi yang baik pada aktivitas pemantauan. Komunikasi lebih banyak dilakukan secara tatap muka, namun demikian mereka juga menggunakan platform whatsapp untuk memudahkan kordinasi. Secara personal sukarelawan Jumantik saling terhubung secara interpersonal dalam beberapa kegiatan seperti arisan, PKK, kegiatan Puskesmas dan Dasa wisma. Pada pelaksanaannya PSN tidak hanya diikuti oleh relawan Jumantik namun juga relawan dari kegiatan lain.

"Kita tim 2 orang kak, disebut kader inti dan pendamping, kalau di wilayah masingmasing. Kalau tadi wilayah gabungan kak, yang disebut dengan PSN RW. Jadi tim nya itu bisa lebih dari 5 orang, karena kan 1 kader jumantik RT 2 orang, 13 RT 26 orang ditambah kader Dasawisma. Dasawisma itu pendataan warga dari data bangunan, individu dan keluarga di RT/RW. Pembagian tugasnya misalkan ada yang nyatet, ada yang ngomong dan ada yang cek jentik pakai senter, gitu gitu."

Kordinasi sebelum PSN dilakukan melalui dua cara: pertama, melalui whatsapp group dan kedua dilakukan dengan cara pertemuan tatap muka sebelum aktivitas PSN. Kordinasi melalui whatsapp group untuk (1) memberikan arahan kebijakan dan strategi (2) menentukan titik kumpul (3) diskusi data minggu sebelumnya untuk menyusun strategi pada minggu berjalan (4) menanyakan kabar sukarelawan atau sebagai wadah silaturahim. Whatsapp group terdiri dari ketua RW 09 dan sukarelawan dari masing-masing RT di bawah RW 09. RW melakukan arahan sesuai kebijakan pemerintah untuk program PSN dan kemudian RW akan meminta kordinator untuk menyampaikan temuan di minggu lalu dan 
pada sesi ini tidak hanya kordinator yang berpartisipatif namun sukarelawan pun diberikan kesempatan untuk dapat mendukung, memverifikasi temuan dan menyampaikan ide terkait temuan tersebut. Selain hal tersebut, whatsapp group juga digunakan untuk silaturahim untuk saling menanyakan kabar anggota yang ada dalam whatsapp group tersebut.

\section{Gambar 1 Komunikasi Partisipatif Perempuan Kader Jumantik}

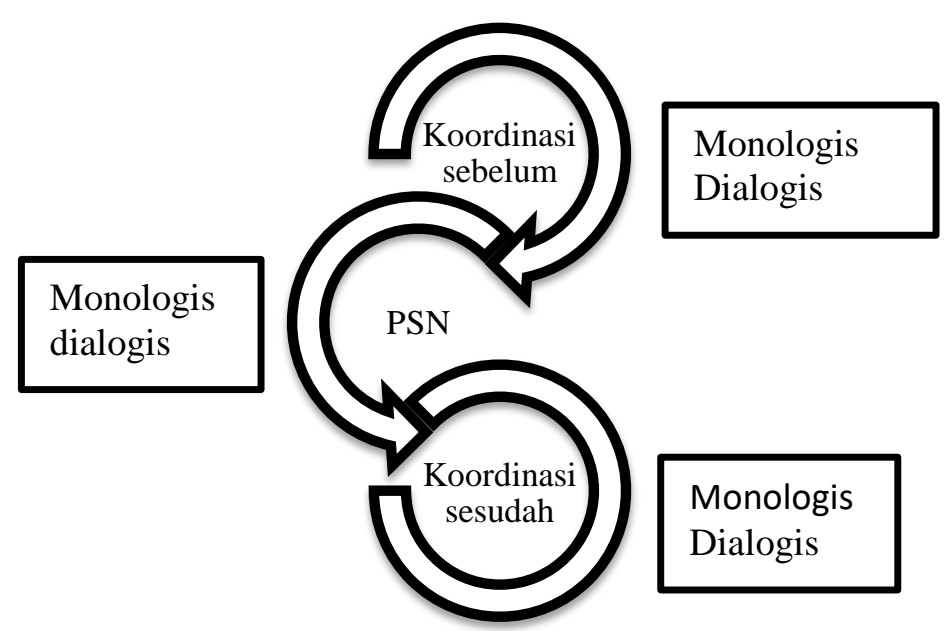

Sumber: Data Olahan Peneliti

Kordinasi sebelum PSN berikutnya dilakukan dengan cara pertemuan tatap muka di titk kumpul yang sudah ditentukan sebelumnya melalui whatsapp group. Acara ini dilakukan sekitar jam 15.15 didahului dengan ramah tamah oleh tuan rumah (titik kumpul) dan arahan dari RW yang nantinya akan menanyakan kesiapan kordinator untuk mengorganisasikan anggotanya untuk keliling melakukan pemantauan. Pada pertemuan ini sukarelawan diwajibkan mengisi daftar hadir, mempersiapkan kebutuhan alat yang akan digunakan selama pemantauan dan area serta jumlah rumah yang akan dikunjungi.

\section{Gambar 2 Ramah Tamah sebelum PSN}

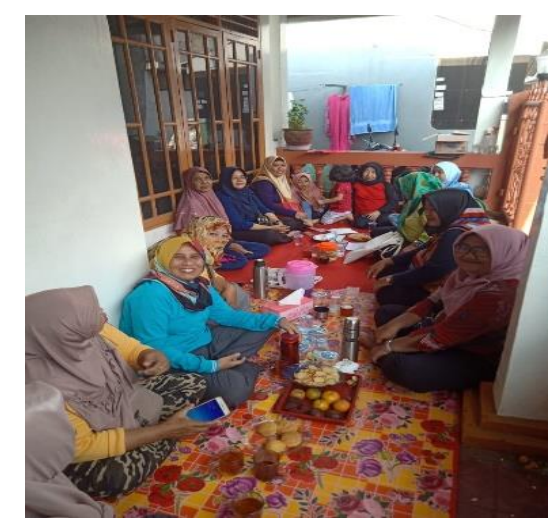

Sumber: Dokumentasi Peneliti

Kunjungan dalam aktivitas PSN ini sukarelawan mempunyai tata cara atau kebiasaan yang mereka lakukan seperti mengetuk pintu dan mengucap salam. Setelah dipersilakan masuk, mereka akan mengecek segala sesuatu yang terdapat penampungan air-bak mandi, 
ember, pot, dispenser. Jika mereka menemukan jentik, mereka akan melakukan konfirmasi kepada pemilik rumah dan memberikan arahan agar tidak terdapat jentik lagi di dalam rumah. Pemilik rumah pun dapat menanyakan dan berdiskusi apa yang seharusnya dilakukan agar rumah bebas dari jentik.

\section{Gambar 3 Temuan PSN}
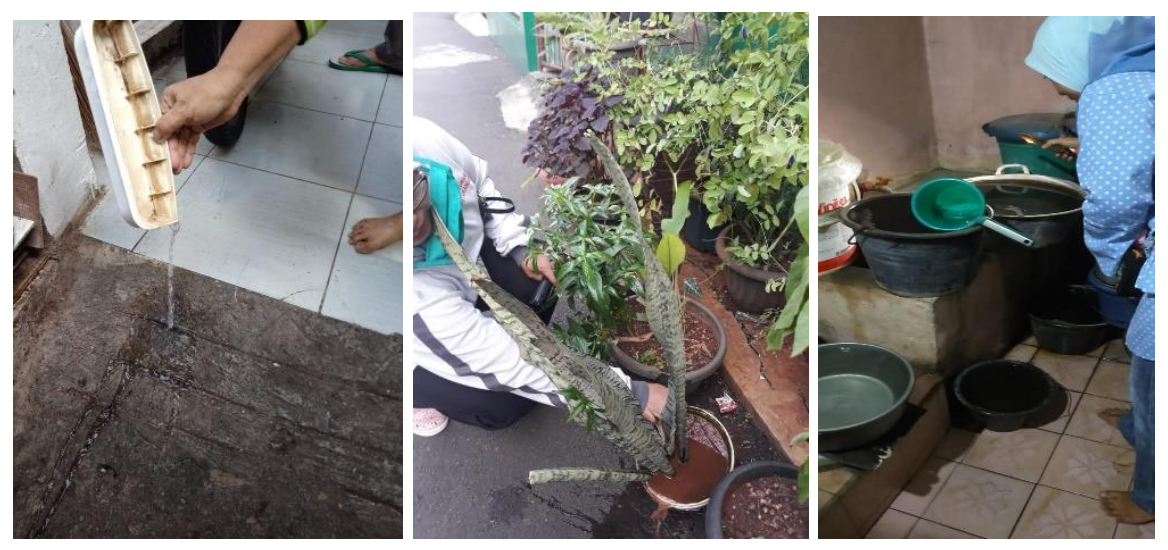

Sumber: Dokumentasi Peneliti

Beberapa dari pemilik rumah yang mereka kunjungi adalah orang yang mereka kenal sehingga mereka saling bertukar kabar. Namun tidak jarang mereka pun mengalami penolakan seperti yang dialami informan 1, 4 dan 5 .

"Ya, pernah. Tapi untuk saat ini udah agak berkurang, penolakannya. Kalau dulu mah banyak, karena mereka belum mengerti, belum paham dan belum tau apa itu manfaatnya, mereka baru denger toh apa itu. "Loh kok rumah aku digobrak gabrik lagi tidur, lagi apa.". Tapi untuk saat ini sudah berkurang, setahun dua tahun lah ya." (Informan 1)

"Ya, pernah, waktu awal-awal, mereka (warga) belum kenal kita, mereka pikir kita mau ambil sumbangan. Belum apa-apa, "Maaf ya bu,...” Kadang-kadang dari jauh mereka udah tutup pintu.” (Informan 4)

"Dulu pertama-tama kita keliling, kita dikiranya mau minta
sumbangan."(Informan 5)

Kordinasi setelah PSN dilakukan setelah aktivitas pemantauan selesai dan sukarelawan kembali di titik kumpul. Mereka melalui kordinator akan menyampaikan temuan berupa catatan mengenai rumah yang memiliki jentik dan titik dimana jentik itu didapatkan. Selain itu mereka juga kegiatan dengan berbagi kisah yang mereka dapatkan selama pemantau hari itu. RW akan meminta para kordinator untuk mendata temuan yang akan dijadikan laporan dan bahan strategi apa yang digunakan untuk meminimalisasi berkembangnya jentik. 


\section{Pembahasan}

Perempuan memiliki komitmen kepedulian untuk menjaga dan meningkatkan kualitas lingkungan dimana mereka tinggal yang salah satunya adalah menjadi sukarelawan juru pantau jentik. Proses yang dilakukan dalam rangka membangun komitmen ini dilakukan melalui komunikasi yang menitikberatkan pada musyawarah atau kesepakatan (Rinawati, 2004). Mereka berpartisipatif dalam pembuatan keputusan dan melakukan pegawasan yang nantinya memberikan manfaat bagi keluarga, komunitas, dan lingkungan sekitar (Asteria, Brotosusilo, \& Apriana, 2018). Keterlibatan perempuan dalam komunikasi partisipatiff ini murni atas panggilan hati dan kesadaran tanpa adanya iming-iming ekonomi berbeda dengan temuan penelitian (Ainiyah, 2016) yang menyatakan perempuan melakukan komunikasi dengan perempuan lainnya dengan tujuan ekonomi.

Sukarelawan juru pantau jentik sebagai obyek riset ini terdiri dari perempuan yang semuanya berprofesi sebagai ibu rumah tangga yang secara sukarela mereka berkomitmen untuk menjaga lingkungan dari jentik nyamuk untuk pemutusan rantai penularan DBD berupa pencegahan terhadap gigitan nyamuk Aedes aegypti dan Aedes albopicus. Sukarelawan ini mampu membuktikan kemampuan mereka untuk memfasilitasi, mediasi, komunikasi dan melakukan kordinasi (Asteria, D., Brotosusilo, A., \& Apriana, I. W. A., 2018).

Dalam konteks komunikasi partisipatif, komunikasi antara orang-orang berkembang bukan pada kemampuan untuk berbicara cepat, tetapi kemampuan untuk mendengarkan dengan baik yang akan menumbuhkan kepercayaan (Servaes \& Malikhao, 2005). Partisipatif, yang mengharuskan mendengarkan, dan terlebih lagi, kepercayaan, akan membantu mengurangi jarak sosial antara komunikator dan penerima, antara pemerintah yang dalam penelitian ini diwakili oleh Kelurahan, RW, RT kepada sukarelawan dan warga. Komunikasi partisipatif memfasilitasi pertukaran ide, pengetahuan, dan pengalaman.

Kader Jumantik mempunyai peran dalam melakukan pemantauan dan oencegahan DBD sebagai berikut: (1) menjadi bagian dari Pemantauan Jentik Berkala (PJB) di lingkungan rumah mereka, (2) memberikan informasi dan edukasi berupa penyuluhan kepada anggota keluarga dan masyarakat di lingkungan mereka, (3) melakukan pencatatan dan pelaporan hasil kegiatan PSN yang dilakukan secara berkala (mingguan dan bulanan) kepada Rukun Warga (RW), kepala desa maupun puskesmas setempat, (4) melakukan kegiatan PSN dan pemberantasan DBD dengan memberikan bubuk abate dan ikan pemakan jentik.

Peran kader kesehatan dalam menanggulangi DBD antara lain, sebagai anggota PJB di rumah-rumah dan tempat umum; memberikan penyuluhan kepada keluarga dan masyarakat; mencatat dan melaporkan hasil PJB kepada kepala dusun atau puskesmas secara rutin minimal mingguan dan bulanan; mencatat dan melaporkan kasus kejadian DBD kepada rukun warga (RW), kepala dusun atau puskesmas; melakukan PSN dan pemberantasan DBD secara sederhana seperti pemberian bubuk abate dan ikan pemakan jentik. Implementasi program PSN dapat dilakukan dengan cara terciptanya komunikasi di antara pemangku kepentingan yang terlibat yang bertujuan agar program dapat terlaksana dengan baik. Pemangku kepentingan tersebut mempunyai tugas yang saling berhubungan dan 
berkesinambungan serta dibutuhkan juga kordinasi untuk mencapai keberhasilan program (Suwarto, Widodo, Samingan, \& Tamri, 2017).

Komunikasi partisipatif dipandang sebagai sarana ampuh yang dapat menfasilitasi proses partisipatif apabila proses tersebut sesuai dengan dinamika pembangunan di tingkat lokal. Proses-proses partisipatif yang dimaksud adalah adanya partisipatif komunitas, yakni adanya keterlibatan aktif kelompok komunitas yang berbeda, bersama-sama pemangku kepentingan lainnya dan beberapa agen pembangunan serta peneliti yang bekerja dengan komunitas serta para pengambil keputusan.

Komunikasi yang berbasis program merupakan komunikasi partisipatif yang terwujud dalam komunikasi monologis, dialogis dan gabungan antara monologis dan dialogis. Komunikasi yang monolog dan dialog terjadi dalam peristiwa komunikasi pada tahap pembentukan kelompok, rapat kerja dalam kelompok, sosialisasi hasil kegiatan kelompok. Komunikasi dialogis terjadi pada pelaksanaan bersifat fungsional yatu pelaksanaan fungsi yang telah dierencanakan sebelumnya. Sedangkan, gabungan komunikasi monologis dan dialogis terjadi pada proses pembentukan kelompok bersifat informatif dan interaktif (Kusumadinata, Sarwoprasodjo, \& Purnaningsih, 2012)

Komunikasi yang dilakukan pada aktivitas kordinasi sebelum PSN merupakan monologis, dialogis dan kombinasi (Tufte \& Mefalopulos, 2009). Monologis terjadi ketika RW menyampaikan arahan dan kebijakan program PSN, kordinator menyampaikan laporan temuan. Dialogis terjadi ketika ada sesi tanya jawab yang bersifat konfirmasi dengan pemaparan temuan oleh kordinator dengan sukarelawan lainnya. Kombinasi terjadi ketika mereka saling menyapa dan membicarakan baik masalah seputar PSN maupun pribadi mereka. Temuan ini senada dengan penelitian tentang komunikasi partisipatori dalam penanggulangan penyakit yang menekankan pada model monologis pada pelatihan dan penyampaian informasi dan dialogis pada pemecahan masalah (Syarah, 2016).

Pada aktivitas PSN, komunikasi yang terjadi adalah komunikasi dialogis antara sukarelawan dengan pemilik rumah. Sukarelawan menyampaikan kondisi rumah yang bebas atau terdapat jentik nyamuk dan pemilik rumah akan bertanya di titik mana jentik ditemukan ataupun bertanya bagaimana memberantas jentik tersebut. Selain itu, ditemukan bahwa terdapat hubungan antarpribadi yang sudah terjalin antara kader dan pemilik rumah sehingga aktivitas pemantauan juga merupakan bentuk silaturahim--masyarakat Indonesia dikenal dengan masyarakat kolektif, senang bergaul, bersilaturahmi, maka sangat senang dengan melakukan komunikasi secara langsung (Suharsono, 2020).

Bentuk komunikasi pada tahap kordinasi setelah PSN berupa kombinasi monologis dan dialogis yang dilakukan oleh RW, kordinator dan jumantik, dan para sukarelawan. Komunikasi kombinasi ini menandakan komunikasi yang efektif karena dalam konteks penelitian ini dan berdasarkan observasi, adanya hubungan yang baik dan terciptanya perasaan senang di antara mereka ketika mereka melakukan komunikasi.

Aminah (2016) menyatakan bahwa peserta komunikasi partisipatif merupakan subjek komunikasi yang artinya mereka memberikan/diberikan, menghargai/ dihargai kesempatan untuk menyampaikan opini mereka. Perempuan sebagai kader jumantik memyadari bahwasanya mereka sedang melakukan partisipatif pada program pemerintah PSN (Pemberantasan Sarang Nyamuk) yang dalam kegiatan ini mereka berbagi informasi, 
pengetahuan, mengidentifikasi dan menyelesaikan permasalahan dan juga menjalin hubungan antarpribadi antar sesama kader. Hal senada juga didapatkan pada penelitian komunikasi partisipatif pemberdayaan keluarga (Satriani, Muljono, \& Lumintang, 2011).

Komunikasi partisipatif perempuan dalam program Pemberantasan Sarang Nyamuk dalam lingkungan mereka tidak hanya dalam konteks program, namun keterlibatan mereka juga berdampak pada hubungan antarpribadi yang terjalin lebih kuat antar kader jumantik dan juga membangun karakter pribadi perempuan kader jumantik di tengah masyarakat. Namun demikian, stakeholder pemerintah diharapkan dapat memberikan pelatihan komunikasi dan teknologi komunikasi bagi perempuan kader jumantik agar implementasi lebih efektif mengingat kompleksitas and heterogenitas warga dari segi demografis untuk kedepannya komunikasi partisipatif dapat lebih memyesuaikan karakteristik masyarakat menggunakan media informasi dan teknologi (Nurjanah, Firdaus, \& Awza, 2020).

\section{PENUTUP}

Berdasarkan hasil riset dapat disimpulkan bahwa Partisipatif perempuan dalam komunikasi partisipatif sebagai sukarelawan jumantik merupakan kesadaran untuk dapat menjaga lingkungan mereka dari jentik nyamuk DBD. Bentuk komunikasi pada tahap kordinasi sebelum PSN monologis, dialogis dan kombinasi. Bentuk komunikasi pada tahap PSN adalah dialogis yang terjadi antara sukarelawan jumantik dalam melakukan aktivitas pemantauan dengan para pemilik rumah yang dikunjungi. Bentuk komunikasi pada tahap kordinasi setelah PSN adalah monologis dan kombinasi. Penelitian ini juga mendapatkan temuan bahwa keterlibatan perempuan dalam komunikasi partisipatif tidak hanya sebatas konteks implementasi program PSN, namun juga berdampak pada pada hubungan antarpribadi yang terjalin lebih kuat antar kader jumantik dan juga membangun karakter pribadi perempuan kader jumantik di tengah masyarakat. Partisipatif perempuan dalam pengawasan lingkungan program PSN juga turut meningkatkan pengetahuan dan keterampilan mereka yang pada akhirnya pengetahuan dan keterampilan tersebut tidak hanya mereka sendiri rasakan namun juga lingkungan masyarakat di mana mereka tinggal. Saran yang dapat disampaikan adalah stakeholder pemerintah diharapkan dapat memberikan pelatihan komunikasi dan teknologi komunikasi bagi perempuan kader jumantik agar implementasi lebih efektif mengingat kompleksitas and heterogenitas warga secara demografis. Rekomendasi untuk penelitian selanjutnya adalah mengenai pengembangan komunikasi partisipatif berbasis gender dalam penyesuaian kondisi pandemi saat ini dan optimalisasi pendekatan multi-track yang kreatif dengan fokus berbasis kepada penggunaan media sosial.

\section{DAFTAR PUSTAKA}

Ainiyah, N. (2016). Peran Komunikasi Kelompok Berbasis Gender. Muwazah, 8(2), 224243. Retrieved from http://e-journal.iainpekalongan.ac.id/index.php/Muwazah/article/ view/757/1131

Aminah, S. (2016). The Application of Participatory Communication in the Implementation of Small Farmers Empowerment Program. Jurnal Bina Praja, Vol. 08, pp. 135-148. 
https://doi.org/10.21787/jbp.08.2016.135-148

Asteria, D., Brotosusilo, A., \& Apriana, I. W. A. (2018). The Role of Women As Environmental Activist in Resolution of Environmental Conflicts for Sustainability of City. KnE Social Sciences, 3(10), 174. https://doi.org/10.18502/kss.v3i10.2911

Febrinastri, F. (2019). Gawat! DKI Jakarta Dilanda DBD, Ini Pencegahannya... Retrieved from https://www.suara.com/news/2019/03/15/160515/gawat-dki-jakarta-dilanda-dbdini-pencegahannya

Hadiyanto. (2008). Komunikasi Pembangunan Partisipatif: Sebuah Pengenalan Awal. Jurnal Komunikasi Pembangunan, 6(2), 81-88. https://doi.org/10.29244/jurnalkmp.6.2.\%p

Kriyantono, R. (2014). Teknik Praktis Riset komunikasi. Jakarta: Prenada Media.

Kusumadinata, A., Sarwoprasodjo, S., \& Purnaningsih, N. (2012). Analisis Komunikasi Partisipasi Dalam Penyelenggaraan Program Perbaikan Gizi Masyarakat (Studi Kasus Pada Kelompok Gizi Masyarakat Pulokerto Kota Palembang). Jurnal Komunikasi Pembangunan, 10(2), 247150. https://doi.org/10.29244/jurnalkmp.10.2.

Morissan, Wardhani, A. C., \& Umarella, F. H. (2012). Metode penelitian survey. Jakarta: Kencana Prenada Media Group.

Nurjanah, Firdaus, M., \& Awza, R. (2020). Model Pengelolaan Komunikasi Berbasis Pemberdayaan Ekonomi di Kawasan Pariwisata Rupat Utara. Jjurnal Riset Komunikasi (JURKOM), 3(2), 239-253. https://doi.org/https://doi.org/10.24329/jurkom.v3i2.162

Pratamawati, D. A. (2012). Peran Juru Pantau Jentik dalam Sistem Kewaspadaan Dini Demam Berdarah Dengue di Indonesia. Kesmas: National Public Health Journal, 6(6), 243. https://doi.org/10.21109/kesmas.v6i6.76

Rinawati, R. (2004). Partisipasi Wanita dalam Pembangunan (Kajian Gender mengenai Partisipasi Wanita dalam Pembangunan Partisipatif melalui Pemberdayaan Masyarakat). Mimbar, XX(3), 387-405. Retrieved from https://webcache.googleusercontent.com/search?q=cache:e399ju96CA8J:https://media. neliti.com/media/publications/157253-ID-partisipasi-wanita-dalampembangunan.pdf $+\& c d=1 \& h l=i d \& c t=c \ln \& \& g l=i d$

Rinawati, R. (2006). Komunikasi dan Pembangunan Partisipatif. Mediator, 7(2), 175-184. https://doi.org/10.29313/mediator.v7i2.1285

Saleh, M. (2014). Partisipasi Perempuan dalam Pengelolaan Lingkungan Hidup Meylan Saleh. 6. No. 2(Musawa), 236-259.

Satriani, I., Muljono, P., \& Lumintang, R. W. . (2011). Komunikasi Partisipatif Pada Program Pos Pemberdayaan Keluarga. Komunikasi Pembangunan, 9(2), 17-27.

Servaes, J., \& Malikhao, P. (2005). Participatory communication: The new paradigm. ... Change. Rethinking Communication. Retrieved from http://biblioteca.clacso.edu.ar/subida/uploads/FTP-test/clacso/coediciones/ 20100824064944/09Chapter5.pdf

Sugiyono. (2019). Metode penelitian kuantitatif, kualitatif, dan $r \& d$. Bandung: CV Alfabeta. Suharsono. (2020). Komunikasi Interpersonal Pokdarwis dalam Meningatkan Kualitas Pelayanan Homestay ( Studi kasus pada komunitas pengelola homestay di Pulau Untun Jawa , Kepulauan Seribu ). Jurnal Riset Komunikasi (JURKOM), 3(4), 161-176. https://doi.org/DOI: https://doi.org/10.38194/jurkom.v3i2.158 
Suwarto, Widodo, S., Samingan, \& Tamri. (2017). Penyuluhan DBD Terhadap Kader Jumantik Rw 09/13 Kecamatan Cipayung Dan Cilangkap Jakarta Timur. Penyuluhan DBD Terhadap Kader Jumantik Rw 09/13 Kecamatan Cipayung Dan Cilangkap Jakarta Timur, 1(1), 24-39.

Syarah, M. M. (2016). Pendekatan komunikasi partisipatori dalam penanggulangan penyakit di kalangan masyarakat miskin. Prosiding Seminar Nasional Komunikasi 2016, VII(September), 447-457.

Tufte, T., \& Mefalopulos, P. (2009). Participatory communication: A practical guide. Retrieved from https://openknowledge.worldbank.org/handle/10986/ $5940+\& \mathrm{~cd}=2 \& \mathrm{hl}=\mathrm{id} \& \mathrm{ct}=\mathrm{clnk} \& \mathrm{gl}=\mathrm{id}$

Yuliani, P. A. (2019). Dinkes DKI Canangkan Satu Kader Jumantik Per RT. Retrieved from https://mediaindonesia.com/read/detail/212535-dinkes-dki-canangkan-satu-kaderjumantik-per-rt 